\title{
China University Student Basketball Competition System Empirical Research under the Circumstance of New Competition System
}

\author{
$\mathrm{Li} \mathrm{Xi}^{*}$
}

School of Physical Sciences, Hefei Normal University, Hefei 230601, China

\begin{abstract}
At present, world sports events become more and more various, but basketball is still one of Chinese youth favorite sports events, Chinese basketball teaching also gradually becomes focus of researching. The paper analyzes Chinese basketball teaching status. Firstly, it studies China university basketball super League cultural background, competition rules, it finds out that China university basketball super league has been constantly carried out reformation since being founded in 2004, it changes from straight final's three out of five sets to competition system of two out of three sets, due to China university basketball super League considers human body physical power factors, it lets competitions to be more humanized; Secondly, through applying optimal solution mathematical model, it studies factors that affect China university basketball super league rapidly development, finds out that these years' competition system reformation plays a crucial roles in China university basketball super league development. With respect to this, in the following several years, it hopes that China takes international basketball super league competition system as evidence, focuses on China University basketball super league competition system transition so that lets Chinese university students to be more suitable to international super league and conveys more excellent talents for Chinese professional basketball.
\end{abstract}

Keywords: Basketball competition system, china university basketball super league, mathematical model, optimal solution, university students.

\section{INTRODUCTION}

Sports undertakings are not only training on physical quality, followed by basketball changing from previous extremely single game and relaxed activities to current comprehensive confrontations that integrate technology, tactics and team strength, Chinese basketball undertakings are always one of Chinese residents most participants sports activities, with economic rapidly development, people concentrate on most potential China university basketball super league [1].

Since China university basketball super league was founded in Beijing in 2004, it has gone through decades of ups and downs; it has come across both opportunity and challenge. With Chinese basketball undertakings further development, Chinese basketball undertakings ask much for talents, demands become larger, nation and society put more emphasis on China university basketball super league development, because China university basketball super league has already become one of main paths to input more basketball athletes with high technology and high level for Chinese professional team in recent years development, with a great deal of foreign professional coaches guiding university students basketball training and technical experience exchange with professional basketball athletes, it lets Chinese university students basketball level to be greatly improved especially in defense aspect, it has great improvements, which lets China university basketball super league to get closer to world super league [2]. But in some aspect, it is still to be improved, as excessive introducing professional players to participate in competitions, which let China university basketball super league development to appear polarization, rich and advantageous basketball teams improve their own rankings because of employing domestic excellent athletes, it suppresses Chinese university students basketball rapidly and stable development. The paper researches on China university basketball super league development under new competition system, makes analysis of issues that Chinese basketball undertaking development comes across and solves them [3]. The paper carries out analysis and researches on opportunities and challenges that China university basketball super league comes across under contemporary circumstance, and then gets following important significance [4]:

I. It researches on whole nation that includes Beijing, Guangdong, Shanghai and other first-tier cities and Hebei and other second and third-tiers universities that participate in China university basketball super league this time, researched institutions are relative extensive, students are representative, which enhances persuasiveness of the paper investigation and research, and lets the paper results to be more scientific [5].

II. The paper proposes more concrete solutions for further clearly finding out problems that China university basketball super league comes across so as to pave the way for Chinese basketball undertakings development.

III. By researching on China university basketball super league, makes further research on enhancing Chinese univer- 
sity students faculty, fields equipment, athletes techniques and others investment problems, and then let Chinese university students' basketball strength to be better and faster developed, and then build firm foundation for China university basketball super league.

In Chinese university campus, basketball has become one of main sports activities that enrich university student's extracurricular life. With recent years China university basketball super league smoothly hosting, it more arouses university young people enthusiasm in basketball. Below are Chinese experts remarkable performances in the aspect. In the article "Chinese university students basketball league operating mechanism research", Zhang Zhi-Dong through researching on China university basketball super league under new competition system, he pointed out : China university basketball super league development stepped into fast track, from recent years statistical analysis, it was clear that Chinese university students basketball techniques had made great progress, especially in fast attack and defense aspects, they were more prominent. China university basketball super league smooth engagement became the only way to transport a great deal of excellent basketball athletes to Chinese professional basketball team and reserve a great deal of talents for Chinese basketball. In the article of "Chinese university students league sustainable development research", Wang Bo utilizes multiple methods, by interviewing and investigating, consulting lots of literature and combining with previous research base, he got : in contemporary China, no matter people and nature, or cultural development, all must follow the sustainable development ideas, basketball culture also had no exception. So-called university students basketball league sustainable development was on the basis of ensuring fairness and rationality, finding out and cultivating Chinese excellent basketball players through China university basketball super league such a platform, and then serving the country such good circulating mode. In the article "Hunan province vocational colleges basketball league research", Peng Yun went into deeper comparative analysis of Hunan province vocational colleges basketball leagues, the thesis put forward: Hunan province vocational colleges basketball leagues were still developing, which still kept paces with university basketball leagues in the aspects of scale, participants amount, players technical level, referees technology and others, because Chinese vocational basketball leagues started late, it lacked of experiences, and confronted people group was lower with respect to university people group quality, which affected vocational colleges basketball league development to great extent.

The paper through referencing several scholars' research results, utilizes contemporary relative advanced mathematical methods, makes quantitative analysis of Chinese universities students' basketball league development and studies competition system regulation, and provides effective and feasible opinions to escort for Chinese basketball undertakings.

\section{CHINA UNIVERSITY BASKETBALL SUPER LEAGUE CURRENT STATUS}

As the saying goes, 'not a radius of no rules', China university basketball super league also has no exception, competition rules are providing guarantee for maintaining China university basketball super league going ahead smoothly, in order to let referees、athletes to better adhere to competition rules, ensure competitions normal operation, when China university basketball super league regulates competitions rules, it invites totally several hundreds of experts and scholars that include domestics and overseas competitions experts together with Chinese experts to formulate more just, fair and reasonable rules for the schedule. China university basketball super league formulation bases on Chinese professional super league rules, it has its own unique rules features, and has specific regulation in participants, coaches, organizational schools and so on. China university basketball super league accords to China geographical positions distinguishing, it divides into south and north two divisions, every division divides into three seasons:

(1) Regular season south and north divisions adopt versus match's round robin, according to every season integral sum total, it ranks, and gains south and north divisions' top four university students team, and goes into next stage competitions.

(2) After playoffs, it will adopt cross to play games.

(3) Final divides winner and runner-up as well as the third and the fourth competition.

According to division, each confrontation team scores as well as each fighting team integration, by digital calculating methods, it goes ahead with two stages cross methods as following Fig. (1).

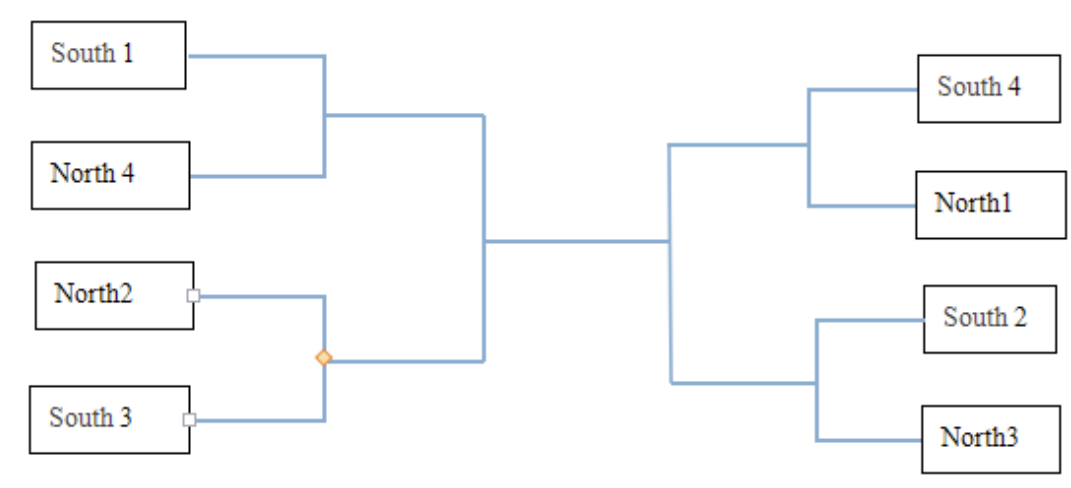

Fig. (1). The playoffs against form cross. 
Table 1. 2004-2005 China university basketball super league reformation table.

\begin{tabular}{|c|c|}
\hline Time & Competition System Changes \\
\hline In 2004 & $\begin{array}{l}\text { China first time hosted university basketball super league, when presently carrying out competition, it divided into south and north } \\
\text { two divisions to play, respectively adopted both at home and away engaged qualification twice round robin system, according to } \\
\text { every game scores, and calculated total scores, then ranked from big to small, and obtained south and north divisions top four univer- } \\
\text { sity students teams and moved towards next phase competition;the second section phase competitions adopted two-way cross knock- } \\
\text { out as above figure;then entered into the third phase competition, and during the third phase competition, it carried out most fierce } \\
\text { winner and runner-up as well as the third and fourth competition, the competition was the conquest among kings, therefore it attracted } \\
\text { attention from all walks of life. }\end{array}$ \\
\hline In 2005 & $\begin{array}{l}2005 \text { was the second year that China university basketball super league organized, after one year researches and summaries, it went } \\
\text { out three versus and two winning elimination way for the second phase playoffs; Among final winner and runner-up, it adopted Chi- } \\
\text { nese traditional regular season ways, hosted five games, basketball team that won three games achieved victory, and increased com- } \\
\text { petition games amount let the competition to become more fierce to absorb more basketball talents for China basketball undertakings. } \\
\text { In } 2005 \text { competition, it adopted } 2004 \text { China university basketball super league applied "basketball rules" that approved by Chinese } \\
\text { basketball association, and executed present stage international basketball league latest competition rules to carry out competitions. }\end{array}$ \\
\hline In 2006 & $\begin{array}{l}\text { Due to recent years participation teams increased, participants range also expanded, China university basketball super league regular } \\
\text { season adopted concentrated tournament system was going ahead with reformation and changes, let it to be more humanized, in every } \\
\text { division, selected two divisions to carry on round robin again; with recovery of playoffs, to at home and away two rounds knock-outs, } \\
\text { final phase most fierce winner and runner-up championship, it also recovered into previous adopted three duels, from which the one } \\
\text { that gained twice victory was the winner. In the session competition, utilized previous China university basketball super league ap- } \\
\text { plied basketball competitions rules, which let the competition to be more fair. }\end{array}$ \\
\hline In 2007 & $\begin{array}{l}\text { On the basis of 2006, made further research on China university basketball super league rules, only adopted two-cycle competition } \\
\text { system on regular season. }\end{array}$ \\
\hline
\end{tabular}

Fig. (2). The number of fans.

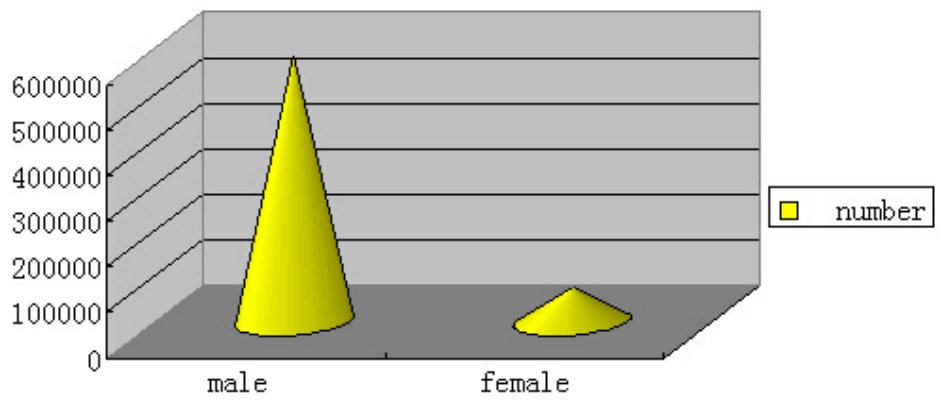

The aim of China university basketball super league rules is "just, fair, open", it should ensure every year competition to carry on normally and also ensure fairness to every team and every athlete, therefore China university basketball super team is constantly perfecting competition rules. Below Table $\mathbf{1}$ is partial reformation change of China university basketball super league during 2004 to 2005 .

China university basketball super league followed by progress of times, development of international globalization, exchanging with international other universities, so that let China university basketball super league competition rules to be further developed, which also marks China university basketball super league gradually goes into maturity, it provides more and more basketball talents guarantee for Chinese professional basketball, and references international basketball super league competition rules, and meanwhile further improves problems that China university basketball super league comes across that promotes China university basketball super league technical levels.

\subsection{China University Basketball Super League Cultural Construction}

No matter which nation, which competition, is financed by enterprises or nations, all have their own cultural values and brand effects, China university basketball super league also has no exception, organizing China university basketball super league carries out concrete investigation and research on their social values, cultural values and other values through experts and scholars from all walks of life.

Vigorous fans: In Chinese youth, no matter what kind of basketball leagues, all haven't more fans than China university basketball super league, because university students are successors of future, and with education system reformation, Chinese university students amount increases, schools attention to university students quality has improved, therefore China university basketball super league has been extensively popularized, so fans enthusiasm in the file rises. Below Fig. (2) is statistics of sport fans amount. 
Table 2. The $2^{\text {nd }}$ China university basketball super league north division stadium brief introduction.

\begin{tabular}{|c|c|c|c|}
\hline $\begin{array}{c}\text { Schools That Participate in } \\
\text { Competitions }\end{array}$ & Name of Home Ground & Clothes Dominant Tone & Stadium Seats Amount \\
\hline Renmin university of China & Century Hall of Renmin university & Red & 3700 \\
\hline Northeast normal university & Air-force university stadium & Blue & 3000 \\
\hline Tianjin university & Tianjin experimental middle school stadium & Blue & 1300 \\
\hline Xi'an Jiaotong university & Xi'an Jiaotong university activity center & Green & 3016 \\
\hline Shandong university & Shandong university campus stadium & Grey & 1200 \\
\hline Liaoning university & Shenyang normal university stadium & Green & 3000 \\
\hline Northeastern university & Northeastern university academic college stadium & Blue & 10015 \\
\hline
\end{tabular}

In China university basketball super league competition field, Chinese university students enthusiasm rises, because they love sports, basketball and prefer to the school basketball player, they shout and cheer in the audience seat, and meanwhile make atmosphere exciting, and also strengthen its own team players wills to fight, basketball fans are indispensable important parts in basketball court, some of them enthusiasm even surpasses athletes on the spot.

Stadium decoration setting: China university basketball super league fields are important guarantees that ensure China university basketball super league to smooth implement, field fixture including light audio-video, utmost is field humidity, temperature, level of smoothness adjustment and maintenance, let players in the field to keep good mood, give maximum technical level into play in the field. Below Table 2 is obtained by consulting information and field decoration status analysis Fig. (3) about China university basketball super league in 2004.

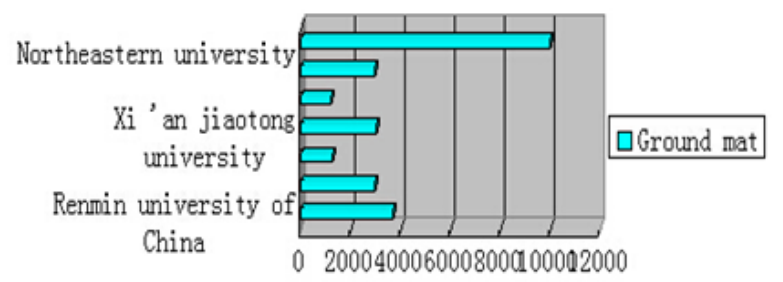

Fig. (3). The second big super league north venue introduction.

Field layout provides guarantee for spreading China university basketball super league culture. Stadium passionate atmosphere, red-and-white China university basketball super league publicity clothes even provides plentiful color and picture for the field. The whole center of field hangs Chinese basketball associations, university student's sports basketball association and other banners. In the field flagpole, it shows each participation basketball team school badge, colors in audience seat clearly distinguishes each delegation supporters. Layout in these fields has been poured efforts of field design experts of all walks of life of China.

China university basketball super league field song and dance: In the development of contemporary society's China university basketball super league, it not only promotes university students physical quality, but also more important popularizes Chinese excellent traditional basketball culture and develops China descendant's basketball spirit. Both China university basketball super leagues opening ceremony and ending ceremony fuse each participation university culture, which let each school excellent culture to be further carried forward. Below Fig. (4) is performance figure of China university basketball super league song and dance.

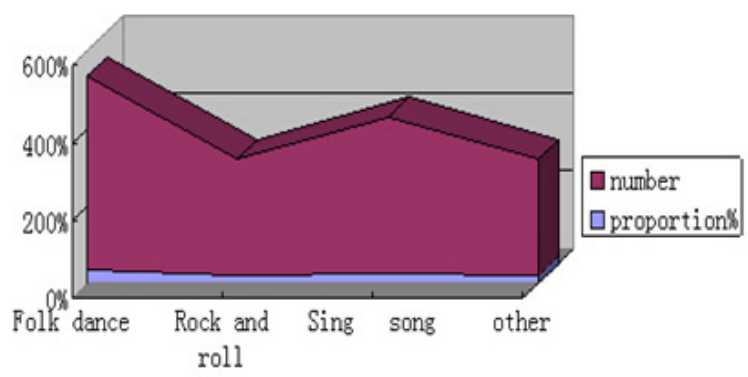

Fig. (4). Dance rock sing other performances.

In the field, performers passions arouse full university students fans enthusiasm in the field, passionate rock, folk dance, dancing dragon, all reflect that China university basketball super league is relative authoritative basketball competition at home, and meanwhile participants sprinkle with sweat for the basketball competition and their own schools honor. China university basketball super league song and dance performing effects cannot be ignored; therefore it should further enrich song and dance performing contents.

\subsection{Optimal Solution Model-Based China University Basketball Super League Developments}

China university basketball super league development attracts attentions from experts and scholars of national all walks of life, because it directly relates Chinese professional basketball players reserve force.

As Fig. (5), all circles, no matter experts, scholars, professors, associate professors, coaches, amateur basketball enthusiasts and so on, all propose relative development opinions to general administration of sport of China, therefore general administration of sport of China must remain responsible attitudes toward whole Chinese basketball teams fans, screen out these opinions and suggestions, and calculate through optimal solution model and then find out most suitable one for China university basketball super league development. 


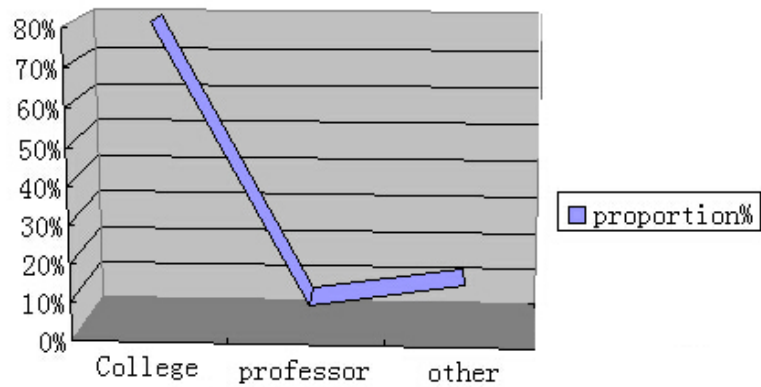

Fig. (5). Professors, students, other fans.

\subsection{Goal Programming Guiding Thought}

As the name suggests, goal programming is programming all given systematical problems by mathematical methods and further getting a group of optimal schemes of practice expected goal. Goal programming overcomes linear programming constraints that only solve a group of linear constraint conditions. In addition, to certain goals, they should have primary and secondary ones, and also mutual supplementation and mutual antagonism. Meanwhile, there is also maximum value, minimum value as well as a difference of quantitative and qualitative, LP cannot solve these problems, while goal programming just overcomes the drawback.

Generally, goal programming has three kinds of methods, weighted coefficient method, priority method and effective solution method. Among them, weighted coefficient method is defining a weight on every solved goal, and further converting complicated multiple goals problems into single goal problems, but its weight rationality is hard to set; priority method is to classify each goal into different grades, its classification evidence is each goal importance. Effective solution can take all goals into account and further get most satisfied solution.

Goal programming objective function common basic form is:

(1)Try to make positive and negative deviation small, and then further just arrive at goal value:

$\min z=f\left(d^{+}+d^{-}\right)$

Try to make positive deviation small, no need to arrive at goal value: $\min z=f\left(d^{+}\right)$

Try to make negative deviation small, surpass goal value and surpass quantity is not limited: $\min z=f\left(d^{-}\right)$

Among them, positive and negative deviation variables definitions are as following:

Known that $d$ is decision variable function, positive deviation variable $d^{+}=\max \left\{d-d_{0}, 0\right\}$ represents the part that calculation value surpasses goal regulated value, negative deviation variable $d^{-}=-\min \left\{d-d_{0}, 0\right\}$ represents the part that calculation value less than goal regulated value, and $d_{0}$ is $d$ goal regulated value, it always has $d^{+} \times d^{-}=0$.
Priority factor: $P_{1}, P_{2}, \cdots$, and it has $P_{k} \gg P_{k+1}, k=1,1, \cdots, q$, which represents $P_{k}$ has bigger priority than $P_{k+1}$.

Goal programming normal mathematical model: Known that $x_{j}(j=1,2, \cdots, n)$ is decision variable of goal programming, it totally has $m$ pieces of constraints, and $l$ pieces of weak goal constraints, its goal programming constraint deviation is $d^{+}, d_{i}^{-}(i=1,2, \cdots, l)$. Set it has $q$ pieces of priorities that are respectively $P_{1}, P_{2}, P_{3}, \cdots, P_{q}$. In the same priority $P_{k}$, weights are different that are respectively $\omega_{k j}^{+}$, $\omega_{k j}^{-}(j=1,2, \cdots, l)$. Therefore goal programming normal mathematical expression is :

$$
\begin{aligned}
& \min z=\sum_{k=1}^{q} P_{k}\left(\sum_{j=1}^{l}{\omega^{-}}_{k j} d_{j}^{-}+\omega^{+}{ }_{k j} d_{j}^{+}\right) \\
& \left\{\begin{array}{l}
\sum_{j=1}^{n} a_{i j} x_{j} \leq(=, \geq) b_{i}, i=1, \cdots, m \\
\sum_{j=1}^{n} c_{i j} x_{j}+d_{i}^{-}-d_{i}^{+}=g_{i}, i=1, \cdots, l \\
x_{j} \geq 0, j=1,2, \cdots, n \\
d_{i}^{-}, d_{i}^{+} \geq 0, i=1,2, \cdots, l
\end{array}\right.
\end{aligned}
$$

\subsection{Goal Programming Data Processing}

Sequential algorithm is according to priority order, transforming complicated multiple goals programming problems into multiple simple goal programming problems, its main process is as following:

At first, most important is China university basketball super league system, therefore its priority is listed into first grade $P_{1}$; Secondly, Chinese university students participation players' quality is the second priority $P_{2}$; finally, it is the third grade field setting that is $P_{3}$. Therefore, it gets corresponding goal programming model:

$$
\begin{aligned}
& \min z=P_{1} d_{1}^{-}+P_{2}\left(d_{2}^{+}+d_{2}^{-}\right)+P_{3}\left(3 d_{3}^{+}+3 d_{3}^{-}+d_{4}^{+}\right)+ \\
& P_{4}\left(3 d_{4}^{+}+3 d_{4}^{-}+d_{5}^{+}\right) \\
& 82.30 x_{1}+10.53 x_{2}+5.74 x_{3}+1.43 x_{4}=3 \\
& 72.58 x_{1}+16.07 x_{2}+9.14 x_{3}+2.22 x_{4}=2.5 \\
& 65.22 x_{1}+20.98 x_{2}+11.54 x_{3}+2.26 x_{4}=1.5 \\
& 59.13 x_{1}+23.63 x_{2}+14.19 x_{3}+3.05 x_{4}=0.75 \\
& 58.12 x_{1}+23.97 x_{2}+14.58 x_{3}+3.33 x_{4}=0.5 \\
& x_{1}, x_{2}, \cdots, x_{i}, d_{i}^{+}, d_{i}^{-} \geq 0, i=1,2, \cdots, 4
\end{aligned}
$$

Calculate above objective function by MATLAB software, and further get goal programming optimal solution is : $z^{*}=(1,2,3)$, and China university basketball super league system is $65.3 \%$. 


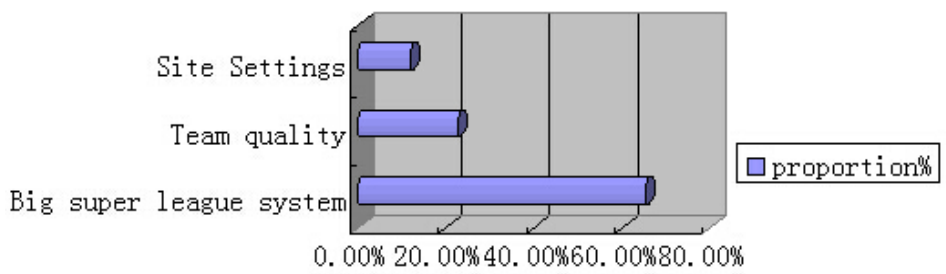

Fig. (6). The results.

\subsection{Result Analysis}

Draw above conclusion into following statistical Fig. (6), and make conclusion analysis according to statistical figure:

From above objective function optimal solution, it can get conclusions: only let China university basketball super league competition system to get closer to world basketball competition system then it will be helpful for China university basketball super league rapidly development, because China university basketball super league competition system accounts for $65.3 \%$ of total proportions. Therefore, China should adapt to national university students such special group of people to carry out assigned China university basketball super league, and meanwhile reference international basketball competitions' rules of competition.

\section{CONCLUSION}

At first, the paper studies China university basketball super league development and cultures, it gets that China university basketball super league development is related to Chinese professional basketball athletes talents supplying status, since China university basketball super league hosted in 2004, China always improves competition systems, and then let China university basketball super league to be more regular, the paper proposes precious opinions on some problems that competition system reformation comes across.

Secondly, by applying optimal solution mathematical model in China university basketball super league and studying on factors that affect China university basketball super league rapidly development, it gets optimal solution model conclusions: in mathematical model, competitions effects account for $65.3 \%$ of total proportions, therefore it concludes that China recent years competition system reformation has greatly promoted China university basketball super league development, which points out directions for Chinese future China university basketball super league development and improvement countermeasures.

\section{CONFLICT OF INTEREST}

The author confirms that this article content has no conflict of interest.

\section{ACKNOWLEDGEMENTS}

This work is supported by the scientific research team of Hefei Normal University: A Study on the HTASSC Multidimensional \& Asynchronous College Physical Education Curriculum Model and the Promotion of College Students' Physical Health.

\section{REFERENCES}

[1] J. Chen, and S. Yao, "Application of connected analysis to analysis of statistical data of basketball technique," Journal of Shanghai Physical Education Institute, vol.33, no. 5, 2009.

[2] F. Fu, Z. Yu, and Q. Zhang, "Analysis of offensive turnover in period of men's basketball final matches at 10th National Games," Shandong Sports Science \& Technology, vol. 28, no.2, pp. 24-25, 2006.

[3] J. Li, "Research on the current situation and developing strategy of chinese track and field coaches," Journal of Shenyang Sport University, vol. 25, no. 2, pp. 63-66, 2006.

[4] J. Mao, and S. Shan, "Basketball technology statistical software development," Journal of Wuhan Institute of Physical Education, vol. 46, no. 2, pp. 70-73, 87, 2012.

[5] L. Zhang, "Analysis on foul in man's basketball final phase in 10th national games," China Sport Science and Technology, vol. 42, no. 1, pp. 50-52, 2006 . 